\title{
Blood over Bond? A Call to Define Kansas's Requirements for Biological Fathers to Retain Parental Rights*
}

\section{INTRODUCTION}

In June 2008, a Kansas couple got the call they had been waiting for. They had been selected as the adoptive parents to a baby girl born just hours earlier. The couple went to the hospital and held their daughter for the first time, beginning the process to legally adopt the girl. The birth mother voluntarily relinquished her parental rights so the couple could file a petition for adoption. ${ }^{1}$ However, one month after the adoption petition was filed, the baby's biological father was located and notified of the pending adoption proceeding, and he asserted his parental rights. ${ }^{2}$ After a two-year legal battle ultimately decided by the Kansas Supreme Court, the adoptive couple found themselves with a court order to turn the child they had raised for two-and-a-half years over to her biological father. ${ }^{3}$

In those two-and-a-half years, the adoptive parents raised the little girl as their own. They celebrated holidays, took photos, and went on vacations. She bonded with her parents and her older sister. One decision by the Kansas Supreme Court caused this little girl to be removed from the only home she had ever known. While the court recognized the gravity of the consequences that accompanied its decision, ${ }^{4}$ it nevertheless chose to abandon years of Kansas adoption law precedent to maintain the biological father's parental rights.

\footnotetext{
* Whitney Novak. J.D. candidate 2014, University of Kansas School of Law; B.S. 2007, University of Kansas. I would like to express my gratitude for the unending support from my family and the University of Kansas Law Review board and staff. I would also like to thank Professor Suzanne Valdez for her invaluable comments during the writing of this Note. This Note is dedicated to M\&M, who courageously fought for the daughter they loved.

1. In re Baby Girl P., 242 P.3d 1168, 1171 (Kan. 2010).

2. Id.

3. See id. at 1176 (remanding to the district court to conduct proceedings to effectuate change of custody).

4. See id. at 1170 ("In this case the courts are again called upon to make the painful determination of whether a child should reside with a natural parent, who has the emotional bonds that follow from biological fatherhood, or with prospective adoptive parents, whose emotional bonds have evolved over many months of loving, supporting, and caring for the child. It is ultimately a
} 
While a biological parent's fundamental constitutional right to parent his child must be protected, ${ }^{5}$ recent Kansas appellate decisions have departed from precedent regarding the standards a biological father must meet to preserve his parental rights. ${ }^{6}$ The Kansas Adoption and Relinquishment Act (KARA) was enacted in 1990 to govern adoptions. ${ }^{7}$ The statute instituted a process for adoptions that "includes both the termination of parental rights and the transfer of legal custody to, and the

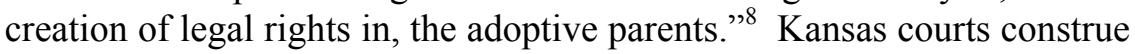
adoption statutes strictly in favor of maintaining the rights of biological parents. $^{9}$

The ambiguity of the Kansas adoption statutes and inconsistency of Kansas courts in interpreting the statutes, however, create unfortunate and detrimental results for children caught in circumstances such as these. KARA must be amended to clarify the standards biological fathers must meet to preserve their parental rights. Additionally, new procedures must be implemented to expedite parental termination appellate proceedings so that a child's status does not remain unresolved for an extended period of time. Although there is a wide array of solutions that could be considered to resolve the problems surrounding the termination of parental rights in favor of adoptions, amending KARA and implementing expedited procedures in termination proceedings are two solutions that could have a positive and immediate effect on Kansas adoptions.

Part II.A of this Note introduces the historical controversy in adoption proceedings by discussing the infamous Baby Jessica case. Part II.B presents background on KARA, specifically section 59-2136 of the

legal decision which this court must reach, but it is a legal decision that is shadowed by the heartbreak of severing human bonds.").

5. See, e.g., Santosky v. Kramer, 455 U.S. 745, 758-59 (1982) (“[A] natural parent's 'desire for and right to the companionship, care, custody, and management of his or her children' is an interest far more precious than any property right." (quoting Lassiter v. Dep't of Soc. Servs., 452 U.S. 18, 27 (1981)) (internal quotation marks omitted)); Quilloin v. Walcott, 434 U.S. 246, 255 (1978) ("We have recognized on numerous occasions that the relationship between parent and child is constitutionally protected.").

6. See, e.g., Baby Girl P., 242 P.3d at 1176 (overturning the appellate court's decision to uphold termination of the biological father's parental rights); In re Baby Girl B., 261 P.3d 558, 560 (Kan. Ct. App. 2010) (concluding that the trial court misinterpreted the statutory grounds to terminate a father's parental rights).

7. Kansas Adoption and Relinquishment Act, ch. 145, 1990 Kan. Sess. Laws 886 (codified as amended at KAN. STAT. ANN. §§ 59-2111 to -2143 (2005 \& Supp. 2012)).

8. 1 Linda D. Elrod \& James P. Buchele, Kansas Family LaW $\S 6.1$, at 310 (1999).

9. See, e.g., In re D.D.H., 184 P.3d 967, 971 (Kan. Ct. App. 2008) (citing In re K.J.B., 259 P.2d 853, 861 (Kan. 1998)). 
Kansas Statutes and the amendments thereto. Part II.C details the facts and procedural history of the recent In re Baby Girl P. case decided by the Kansas Supreme Court, and Part II.D examines prior Kansas appellate decisions regarding the termination of parental rights in pending adoptions. Part II.E discusses the Kansas Legislature's recent attempt to amend section 59-2136 in response to the Baby Girl P. decision, and Part II.F examines the constitutional rights of both children and biological parents and the effect of those rights in adoption proceedings. Part III then addresses the effect of Baby Girl P. on future adoptions in Kansas and the detrimental effect of uncertainty in adoptions. Part III also proposes solutions to resolve the unpredictability that may arise in custody disputes surrounding a pending adoption.

\section{BACKGROUND}

\section{A. Adoption Controversy in Recent History}

Adoption is defined as a "means of creating a legal relationship of parent and child between persons who were not so related by nature or law." 10 Procedurally, adoption severs the legal relationship between birth parents and children and "change[s] the status of the child in relation to its adoptive parents," creating a new parent-child relationship. $^{11}$ Generally, the consent of the biological parents is required for an adoption to be valid, absent statutory circumstances making consent unnecessary. ${ }^{12}$

Recent statistics from the Department of Health and Human Services state that "approximately 136,000 children were adopted annually in the United States" in 2007 and 2008. ${ }^{13}$ While a large percentage of these adoptions resulted in the successful formation of a new parent-child relationship, some statistics suggest that disruption and dissolution rates can range from as high as twenty percent, to as low as less than one-tenth of one percent. ${ }^{14}$ Although rare, cases of infant adoption disruption, specifically involving the rights of biological parents, have caused

10. 2 C.J.S. Adoption of Persons $\S 1$ (2003).

11. Id.

12. Id. $\S 55$.

13. Children's Bureau, U.S. Dep'T of Health and Human Servs., How Many Children WERE ADOPTED IN 2007 AND 2008?, at 4 (2011), available at https://www.childwelfare.gov/pubs/ adopted0708.cfm.

14. Jeanette Mills, Comment, Unwed Birthfathers and Infant Adoption: Balancing a Father's Rights with the States Need for a Timely Surrender Process, 62 LA. L. REV. 615, 615 (2002). 
controversy for decades. In the early 1990s, the Baby Jessica case ${ }^{15}$ gripped the nation and brought to light the doubt and uncertainty that can surround adoption. Baby Jessica was born to a single mother in Iowa and given up for adoption to a Michigan couple shortly after her birth. ${ }^{16}$ Within two weeks of the custody grant, the biological mother moved to revoke her relinquishment, stating she had lied about the identity of the biological father. ${ }^{17}$ The biological father also asserted his rights, and after a year of litigation, the Iowa Supreme Court affirmed the lower court's decisions to revoke the relinquishment and send Baby Jessica back to her biological parents. ${ }^{18}$ The Iowa Supreme Court also rejected the adoptive parents' assertion that a best interests analysis governed the issue of termination in an adoption case. ${ }^{19}$ Although the adoptive parents' custodial rights were terminated, they petitioned a Michigan court to modify the Iowa order. $^{20}$ The Michigan Supreme Court ultimately held Michigan did not have jurisdiction over the adoption ${ }^{21}$ and that Baby Jessica's interest in family life was not independent of her biological parents' interest in raising her, ${ }^{22}$ absent a finding of parental unfitness. $^{23}$

The custodial struggle for Baby Jessica made national news and pitted the biological parents against the prospective adoptive parents with whom Baby Jessica had lived for two-and-a-half years. ${ }^{24}$ The case ignited a national debate about the best interests of the child after the nation watched Baby Jessica sob as she was removed from the only parents she had known to be returned to her biological parents in Iowa, who were strangers to her. ${ }^{25}$ National polls indicated most Americans supported the adoptive parents, and commentators warned of the potentially lingering damage the separation would cause Baby Jessica. ${ }^{26}$ Numerous law review articles published soon after the decision analyzed the state of the law and called for courts and legislatures to reevaluate

15. In re Baby Girl Clausen, 502 N.W.2d 649 (Mich. 1993) (per curiam).

16. Id. at 652 .

17. Id.

18. Id. at $652-53$.

19. Id. at 653 .

20. Id.

21. Id. at 659 .

22. Id. at 665 .

23. Id. at 666 .

24. See Michele Ingrassia \& Karen Springen, She's Not Baby Jessica Anymore, Newsweek, Mar. 21, 1994, at 60, 60, available at http://www.thedailybeast.com/newsweek/1994/03/21/ she-s-not-baby-jessica-anymore.html.

25. Id.

26. See id. 
adoption laws and procedures to prevent future Baby Jessica catastrophes. ${ }^{27}$ Ten years after Baby Jessica, however, Kansas courts are still struggling to define a consistent standard to prevent traumatic removals of children who have been in the custody of adoptive parents for an extended period of time.

\section{B. Kansas Adoption and Relinquishment Act}

Kansas adoptions are governed by KARA, which was passed in 1990 to consolidate existing adoption and relinquishment statutes in Kansas. ${ }^{28}$ The Kansas Judicial Council's Family Law Advisory Committee primarily drafted KARA after the Kansas Senate attempted to change and recodify the Kansas adoption statutes in $1987 .^{29}$ The committee hoped to achieve "greater clarity" in application of the adoption statutes. ${ }^{30}$

\section{Section $59-2136$}

Section 59-2136 of KARA applies when "relinquishment or consent to an adoption has not been obtained from a [biological] parent." ${ }^{\prime 31}$ The provisions of section 59-2136 set standards for when termination of parental rights is acceptable in both stepparent and non-stepparent adoptions. $^{32}$ In non-stepparent adoptions, if a birth mother consents to the adoption of her child, a petition is filed to terminate parental rights of the father. ${ }^{33}$ Notice of the adoption proceeding must then be "given to every person identified as the father or a possible father," 34 and if a father

27. See, e.g., Lynn Kirsch, Note, Unwed Fathers and Their Newborn Children Placed for Adoption: Protecting the Rights of Both in Custody Disputes, 36 ARIZ. L. REV. 1011, 1026-29 (1994) (proposing a two-tiered approach that "considers the biological father's fitness to be a custodial parent, and then considers any detriment that might occur if the child is placed with the biological father"); Carrie L. Wambaugh, Comment, Biology Is Important, but Does Not Necessarily Always Constitute a "Family": A Brief Survey of the Uniform Adoption Act, 32 AKRON L. REV. 791, 831-32 (1999) (recommending the Uniform Adoption Act as a solution to prevent more "tragic stories" in adoption).

28. See Family Law Advisory Committee, Kan. Judicial Council, Comments to 1990 ADOPTION AND RELINQUISHMENT ACT 1 (1990), http://www.kansasjudicialcouncil.org/Documents/ Studies\%20and\%20Reports/Previous\%20Judicial\%20Council\%20Studies/PDF/1990_Adoption_\%2 0Relinquishment_Comments.pdf.

29. See id.

30. Id.

31. KAn. StAT. ANN. § 59-2136(a) (Supp. 2012).

32. See id. §59-2136(d)-(e).

33. Id. §59-2136(e).

34. Id. § 59-2136(f). 
cannot be identified, the court must terminate the unknown father's parental rights. ${ }^{35}$ If a father is identified and asserts his parental rights, the court must determine parentage and then may terminate his rights by clear and convincing evidence of any of the following:

(A) The father abandoned or neglected the child after having knowledge of the child's birth;

(B) the father is unfit as a parent or incapable of giving consent;

(C) the father has made no reasonable efforts to support or communicate with the child after having knowledge of the child's birth;

(D) the father, after having knowledge of the pregnancy, failed without reasonable cause to provide support for the mother during the six months prior to the child's birth;

(E) the father abandoned the mother after having knowledge of the pregnancy;

(F) the birth of the child was the result of rape of the mother; or

(G) the father has failed or refused to assume the duties of a parent for two consecutive years next preceding the filing of the petition.

In determining whether the father's parental rights should be terminated, the court may "disregard incidental visitations, contacts, communications or contributions.",37

\section{The Parental Preference Doctrine}

Before KARA, the Kansas Supreme Court applied the parental preference doctrine to determine whether to terminate parental rights in an adoption proceeding. ${ }^{38}$ In Sheppard v. Sheppard, the Kansas Supreme Court, reviewing a lower court's adjudication of a custody dispute between a child's mother and grandparents, reversed the lower court's decision that it was in the best interest of the child to remain with his maternal grandparents. ${ }^{39}$ Employing the Due Process Clause of the

35. Id. $\S 59-2136(\mathrm{~g})$.

36. Id. §59-2136(h)(1).

37. Id. $\S 59-2136(\mathrm{~h})(2)(\mathrm{B})$.

38. See Sheppard v. Sheppard, 630 P.2d 1121, 1123-25 (Kan. 1981) (discussing the history and reasoning behind the parental preference doctrine).

39. Id. at 1128 . 
Fourteenth Amendment, the court determined the mother had a fundamental, constitutional right to the "care, custody and control of . . . her child, and that the right of such a parent to custody of the child cannot be taken away in favor of a third person, absent a finding of unfitness on the part of the parent." 40 Further, the mother could not be denied her parental rights solely because a court determined someone else could better raise the child. ${ }^{41}$ The Kansas Supreme Court affirmed the parental preference doctrine in In re Guardianship of Williams when it declined to apply solely a test based on the best interest of the child in a custody dispute between a biological parent and third-party nonparent. ${ }^{42}$

After KARA, however, the Kansas Court of Appeals declined to apply the parental preference doctrine when deciding whether to terminate parental rights in an adoption proceeding. ${ }^{43}$ In In re Baby Boy $N$., the court found that section 59-2136(h) incorporated the parental preference doctrine by requiring a showing of "clear and convincing" evidence of at least one of the seven grounds for termination before a court may terminate a biological parent's rights. ${ }^{44}$ According to the court, section 59-2136(h) sufficiently protects the biological parent's due process rights. ${ }^{45}$ In adoption cases where the biological parent's rights are at issue, section 59-2136(h) prevails over the parental preference doctrine because the doctrine is "nothing more than a rule of law designed to protect the constitutional due process rights of a natural parent to the custody of his or her children." ${ }^{46}$ The court found that the "protections incorporated within [section 59-2136(h)] provide the same, if not better, protection of a parent's constitutional rights."

\footnotetext{
40. Id.

41. Id. at 1127.

42. 869 P.2d 661, 670 (Kan. 1994) ("[A]bsent highly unusual or extraordinary circumstances the parental preference doctrine is to be applied in a custody dispute over minor children when the dispute is between a natural parent who has not been found unfit and a nonparent. Likewise ... the best interests of the child is the appropriate standard to be applied in custody disputes between parents.").

43. See In re Baby Boy N., 874 P.2d 680, 688 (Kan. Ct. App. 1994) (concluding that the parental preference doctrine is preempted by statute).

44. See id.

45. Id.

46. Id.

47. Id.
} 
3. Amendments to Section 59-2136

Due to the sensitive nature of section 59-2136 cases and the complexity inherent in the termination of parental rights, the statute has evolved since its enactment in 1990. In 2006, the legislature amended the statute to allow a court to consider the best interests of the child when determining whether parental rights should be terminated. ${ }^{48}$ However, Kansas courts have put little force behind this amendment since its passage in 2006. While the statute permits courts to consider the best interests of the child, courts have interpreted it with the understanding that the Kansas Legislature did not intend that the best interests considerations ever be the sole grounds for terminating parental rights. ${ }^{49}$ Instead, courts have construed the statute to permit consideration of the child's best interests only after the court has found at least one circumstance listed in section 59-2136(h)(1). ${ }^{50}$ Further, "the best interests consideration merely 'provides the court with additional discretionary powers to consider the best interests of the child in denying the adoption - even where a natural parent has not assumed the duties of a parent as articulated by this court-for unique reasons." 51 While a court may decide that termination may be in the best interest of the child, it must refuse to terminate parental rights absent clear and convincing evidence of any of the factors listed in section 59-2136(h)(1). ${ }^{52}$ The Kansas Court of Appeals utilized the best interests test when it affirmed a stepparent adoption in 2012 in In re C.A.T. ${ }^{53}$ The court found the biological father had met several of the statutory grounds for termination $^{54}$ and further that the termination of his rights was in the best interest of the children because the stepfather had "stable employment, had a good relationship with the children for several years, and that [the biological father] had not been fulfilling the duties of a parent."

48. Act of Mar. 20, 2006, ch. 22, sec. 1, § 59-2136(h)(2)(A), 2006 Kan. Sess. Laws 53. In its current state, the statute reads: "In making a finding whether parental rights shall be terminated under this subsection, the court may: (A) Consider and weigh the best interest of the child." KAN. STAT. ANN. § 59-2136(h)(2)(A) (Supp. 2012).

49. See, e.g., In re Baby Boy M., 193 P.3d 520, 528 (Kan. Ct. App. 2008).

50. See, e.g., id.

51. Id. (emphasis added) (quoting In re G.L.V., 190 P.3d 245, 265 (Kan. 2008)).

52. See id. at 527 (stating that "the district court failed to make any of the requisite findings to support a termination of ... parental rights, except an apparent finding as to the best interests of the child," which was insufficient).

53. 273 P.3d 813, 821 (Kan. Ct. App. 2012).

54. Id. at 815-16.

55. Id. at 821 . 


\section{In re Baby Girl P.}

Cases regarding the termination of parental rights under section 592136 often require courts to make difficult legal decisions while simultaneously detaching from the highly charged emotions that accompany such situations. A 2010 Kansas Supreme Court case, In re Baby Girl P. ${ }^{56}$ was one such case. Baby Girl P. was born in June 2008. ${ }^{57}$ Her biological mother placed her for adoption shortly after birth and selected an adoptive couple, who filed a petition for adoption a few weeks later. ${ }^{58}$ Baby Girl P. was conceived during her biological mother's extramarital affair. ${ }^{59}$ After discovering she was pregnant, the biological mother notified the biological father. ${ }^{60}$ There was conflicting testimony at trial as to the biological father's interest in and excitement about the news; however, testimony showed that the biological mother told the biological father via text message that she had suffered a miscarriage and did not want him to contact her anymore. ${ }^{61}$ The biological father claimed he had no reason to question the truth of the biological mother's text message, which was corroborated by a friend of the biological mother who claimed she thought the biological mother was "no longer pregnant." "62 For six months prior to the birth of Baby Girl P., the biological father did not provide any emotional or financial support to the biological mother. ${ }^{63}$

After Baby Girl P. was born and taken into her prospective adoptive parents' custody, the biological father learned of the adoption proceeding and obtained counsel to protect his parental rights. ${ }^{64}$ An evidentiary hearing regarding the parental right issue was held nearly six months after Baby Girl P.'s birth. ${ }^{65}$ In the period between the biological father learning of Baby Girl P.'s birth and the evidentiary hearing regarding his parental rights, the biological father visited the child only twice, wrote one letter to the prospective adoptive parents offering his support, and delivered Christmas presents to the adoption agency to be sent to Baby

\footnotetext{
56. 242 P.3d 1168 (Kan. 2010).

57. Id. at 1170 .

58. See id. at 1171 .

59. See id. at 1170 .

60. Id.

61. Id. at 1171.

62. Id.

63. See id.

64. See id.

65. Id.
} 
Girl P. ${ }^{66}$ These gifts included a "handmade quilt, three or four shirts, and two baby bibs." 67 After the evidentiary hearing, the district court terminated the biological father's parental rights, finding: "(1) that he had failed to support the child after learning of her birth, and (2) that the child's best interests would be served by terminating [the biological father's] parental rights." ${ }^{, 68}$ In support of its findings, the district court noted that the biological father had "not "provided or offered financial support' for the child even though he had a job" with an annual salary of $\$ 25,000 .^{69}$ Further, he did not file a separate paternity lawsuit, ${ }^{70}$ which could have mandated parenting time with the child and established an order of financial support. ${ }^{71}$ The district court then weighed the best interests of the child pursuant to section 59-2136(h)(2) and concluded "[t]he best interest of [the child] tips the evidentiary scale for this court in concluding that [the biological father's] parental rights ... should be terminated." $" 72$

The biological father appealed more than a year later, and the Kansas Court of Appeals affirmed the district court's decision to terminate his parental rights, stating that "the district court's factual findings regarding a failure to provide financial support and the child's best interests were supported by substantial evidence and by Kansas case law, especially the A.A.T., M.R.C., M.D.K., and Baby W. cases."73

The Kansas Supreme Court granted the biological father's petition for review and reversed the decision of the Kansas Court of Appeals, ${ }^{74}$ essentially overruling years of Kansas adoption precedent. The court determined that the prospective adoptive parents had failed to prove by clear and convincing evidence that the biological father had failed to support Baby Girl P., finding instead that his behavior demonstrated a

\footnotetext{
66. Id.

67. In re Baby Girl P., No. 1022,287, 2010 WL 348291, at*1 (Kan. Ct. App. Jan. 22), rev'd, 242 P.3d 1168 (Kan. 2010).

68. Id. at $* 2$.

69. Id. at $* 1$.

70. Id.

71. KAN. StAT. ANN. § 23-2204(b) (Supp. 2012) (providing that the rights and responsibilities of acknowledgement of paternity include, among other things, providing support for the child and custody and parenting time).

72. Baby Girl P., 2010 WL 348291, at *1 (first, second, and fourth alterations in original) (internal quotation marks omitted).

73. See id. at *5 (noting In re A.A.T., 196 P.3d 1180 (Kan. 2008); In re M.R.C., 217 P.3d 50 (Kan. Ct. App. 2009); In re M.D.K., 58 P.3d 745 (Kan. Ct. App. 2002); In re Baby W., 210 P.3d 687 (Kan. Ct. App. July 10, 2009) (per curiam) (unpublished table decision)).

74. In re Baby Girl P., 242 P.3d 1168, 1172, 1176 (Kan. 2010).
} 
desire to maintain a relationship with his child. ${ }^{75}$ Notably, the court emphasized that the state had a strong interest in preserving biological parental rights, ${ }^{76}$ stating that "the law presumes that the father starts out with a parental relationship; it is his to abandon, not to conquer.",77

\section{Kansas Case Law Prior to In re Baby Girl P.}

The Kansas Supreme Court's decision in In re Baby Girl P. disregarded years of precedent set by Kansas appellate courts regarding the termination of parental rights. In 2002, the Kansas Court of Appeals upheld the termination of a father's rights in In re M.D.K. ${ }^{78}$ In M.D.K., the biological father knew of the pregnancy but failed to support the mother for six months prior to the child's birth. ${ }^{79}$ The evidence showed that although the father worked full-time for part of the six months and lived rent-free with his parents, he did not contribute any of his wages to the child's mother. ${ }^{80}$ His parents bought the biological mother's car from her to alleviate her financial difficulties, and his mother and grandmother made a quilt for the baby and delivered it along with some baby clothes to the biological mother. ${ }^{81}$ Further, the biological mother told the birth father to stop calling her, and the biological father asserted that the biological mother "made no requests for money and, instead, told him everything was going well and that she did not need anything." Kansas Court of Appeals found that "the term 'support' does not include a requirement that 'the father provide total support for the mother... [but] support that is incidental or inconsequential in nature is not sufficient." 83 For support to be sufficient, it "must be of some consequence and reasonable under all of the circumstances." ${ }^{84}$ The court also found that support must include the "natural and moral duty of a parent to show affection, care and interest toward his or her child" $" 85$ and

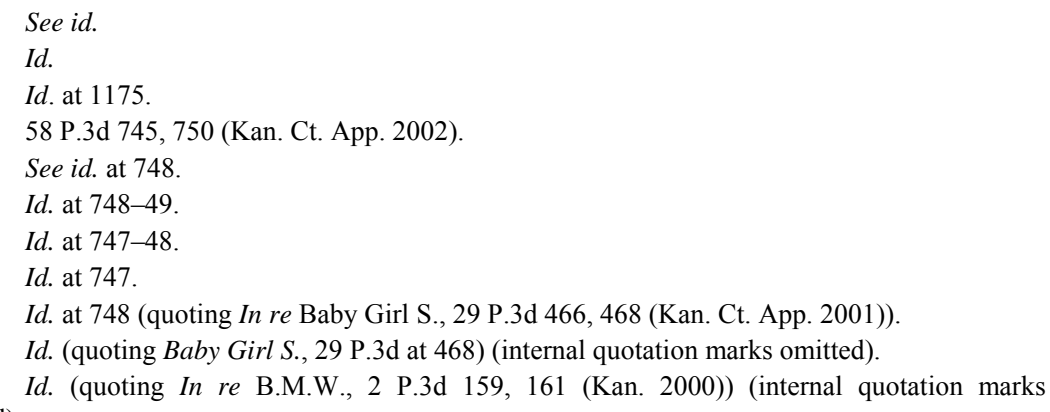


"mere general offers of support are not sufficient." ${ }^{\text {" }}$ While the father argued that he was prevented from providing support by the mother's actions, the court noted that a father must pursue "the opportunities and options which were available to carry out his duties to the best of his ability." ${ }^{87}$ And while a mother's refusal of assistance is one factor in considering whether the father adequately provided support to the mother, ${ }^{88}$ "a mother's failure to act upon a general offer of assistance by not contacting the father and telling him what she specifically need[s] does not amount to interference or a refusal of financial help." 89 The court noted that termination is appropriate if a father makes only general offers of support and that he must "act affirmatively during the mother's pregnancy to protect his rights to the child." $" 90$

Notably, Judge Beier wrote separately in a concurring opinion to emphasize that putative fathers must be aware of the implications of the court's decision:

An unwed man who learns that his unwed sexual partner is pregnant and intends to carry the pregnancy to term has only one way to ensure he can exercise his parental rights after the birth, regardless of whether the mother intends to exercise hers: He must relinquish possession and control of a part of his property or income to the mother-to-be during the last 6 months of the pregnancy so that she may use the items or money to support herself or prepare for the arrival of the child. He must do this regardless of whether his relationship with the mother-tobe continues or ends. He must do this regardless of whether the mother-to-be is willing to have any type of contact with him whatsoever or to submit to his emotional or physical control in any way. The birth may be the event that triggers a legal obligation of support, but it marks the end of the period when voluntary support can preserve the father-to-be's right to raise his child. ${ }^{91}$

Judge Beier suggested that "[e]ven in the most acrimonious of situations, a father-to-be can fund a bank account" for the mother or "have property or money delivered to the [mother] by a neutral third

\footnotetext{
86. Id. (citing Baby Girl S., 29 P.3d at 469).

87. Id. at 749 (quoting In re Baby Boy W., 891 P.2d 457, 461 (Kan. Ct. App. 1994)) (internal quotation marks omitted).

88. Id. (citing Baby Girl S., 29 P.3d at 469).

89. Id. (alteration in original) (quoting Baby Boy W., 891 P.2d at 461) (internal quotation marks omitted).

90. Id. (quoting Baby Girl S., 29 P.3d at 468).

91. Id. at 750 (Beier, J., concurring).
} 
party ... and must ... be as creative as necessary" to provide assistance to the mother regardless of her hostility or lack of interest in him. ${ }^{92}$

Relying on precedent from In re M.D.K., the Kansas Court of Appeals also upheld the termination of a biological father's rights in In re M.R.C. ${ }^{93}$ Similar to the facts in Baby Girl P. ${ }^{94}$ M.R.C.'s biological mother misled M.R.C.'s biological father by saying she had miscarried. ${ }^{95}$ The court found that passively accepting the rumor that the biological mother had miscarried was not a defense to failing to provide support because "a father has a duty to take affirmative action to manifest a full commitment to parenting responsibilities." $"$ The court additionally required the father to "exercise reasonable diligence to discover whether the mother has lied to him concerning the existence of the child."

Further building on this trend, the Kansas Court of Appeals upheld termination of the rights of a father in In re Baby $W .^{98}$ because he failed to make "reasonable efforts to support or communicate with Baby W. after learning of the child's birth." had miscarried, the mother gave birth to Baby W. and made arrangements for the child to be adopted shortly after. ${ }^{100}$ When the biological father was located, he filed an acknowledgement of paternity, stating he was "ready and willing" to receive residential custody of the baby as soon as possible. ${ }^{101}$ The district court terminated the father's rights because after learning of his child, the "father had "made no reasonable efforts to support or communicate with the child.",102 On appeal, the biological father argued that "he did everything asked of him to retain his parental rights," but it was unreasonable for him to visit the child in Kansas because he lived in Virginia. ${ }^{103}$ At an earlier hearing, he admitted that he had provided no support for the child, but then stated he had " "every intention' of reimbursing the adoptive parents" for their care of Baby W. ${ }^{104}$ The court upheld termination of his parental rights

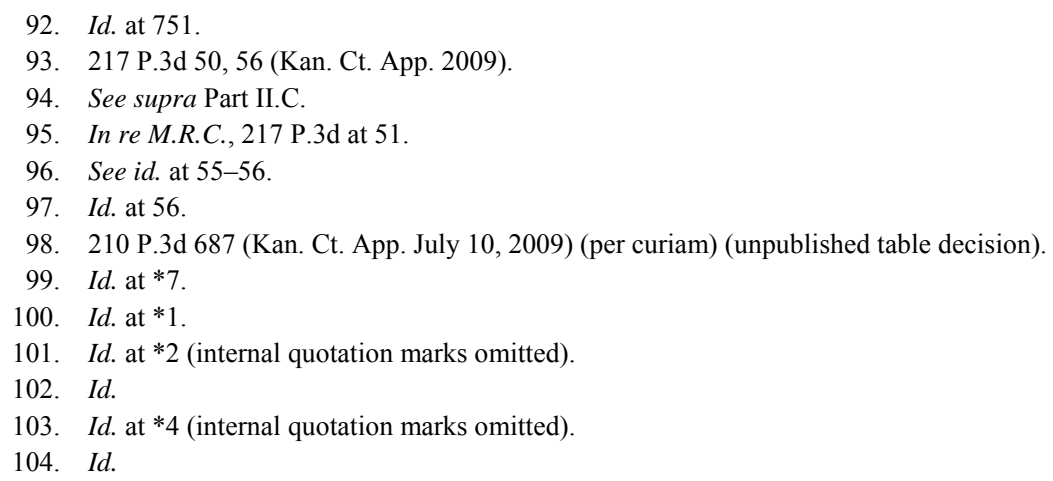


because "it is insufficient for a father to merely stand ready, and the father should have taken affirmative action to provide support for Baby W. upon learning of the child's birth rather than waiting to see what the court might eventually order." 105

In a comprehensive analysis of putative fathers' rights, the Kansas Supreme Court upheld the termination of a biological father's parental rights in In re A.A.T. after his rights were terminated without his knowledge. ${ }^{106}$ The biological mother and father had a short relationship and conceived A.A.T. ${ }^{107}$ The biological mother informed the father she was pregnant before she moved from New York to Wichita but later told him she had undergone an abortion. ${ }^{108}$ The biological father continued to ask the mother about her pregnancy and was skeptical she had actually had gone through with the abortion. ${ }^{109}$ For a period of time spanning immediately before and immediately after A.A.T.'s birth, the biological father and mother continued communicating via telephone, and the biological father persistently expressed his doubts regarding the mother's truthfulness about the termination of her pregnancy. ${ }^{110} \mathrm{He}$ made statements such as, "I know I have a child, I can feel it" and predicted to a friend that the child was a daughter. ${ }^{111} \mathrm{He}$ even purchased earrings as a Christmas gift for the child he thought he had. ${ }^{112}$ After A.A.T.'s birth, the biological mother continued to lie, telling her family members and friends the baby died at birth and deceiving the adoption agency regarding the identity of the biological father and his whereabouts. ${ }^{113}$ She also lied during the adoption proceeding and at an interview with a guardian ad litem, claiming she had not had contact with the biological father since her second month of pregnancy and giving a false surname for him on an affidavit. ${ }^{114}$ In the absence of any reliable information about the real biological father, a notice was placed in the New York Post regarding the birth of A.A.T. ${ }^{115}$ After no father appeared, the court terminated parental rights and finalized the adoption decree for A.A.T. ${ }^{116}$

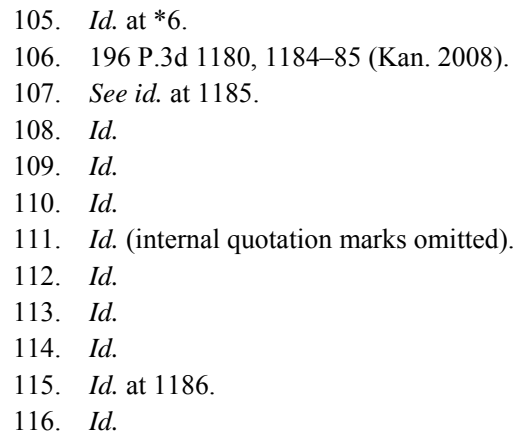


When A.A.T. was six months old, her biological mother finally told the biological father the truth about A.A.T.'s birth, and within six weeks the biological father retained counsel to set aside the adoption proceeding. ${ }^{117}$ After a DNA test confirmed the biological father's paternity, he sought to set aside the adoption and requested visitation rights with A.A.T. ${ }^{118}$ The district court refused to set aside the adoption decree and ruled that because the father suspected the mother was still pregnant, he should have taken affirmative action to determine the truth. ${ }^{119}$

After a lengthy analysis of the history of putative fathers' rights, the Kansas Supreme Court reaffirmed the district court's decision to terminate. The court synthesized the holdings from putative father cases from the United States Supreme Court and newborn adoption cases across the country and found the emergence of two common factors. ${ }^{120}$

[A] putative father has a liberty interest affording a right to notice of proceedings to adopt his newborn child if he: (1) diligently took affirmative action that manifested a full commitment to parenting responsibilities and (2) did so during the pregnancy and within a short time after he discovered or reasonably should have discovered that the biological mother was pregnant with his child. ${ }^{12}$

The court found the first factor could be proven by "measur[ing] the putative father's efforts to make a financial commitment to the . . child" and by the father "legally substantiat[ing] his relationship with the child" in addition to providing support, including emotional and financial, to the mother during her pregnancy. ${ }^{122}$ The second factor required the father "to make a commitment to parenting ... in a prompt and timely manner as measured by the fleeting opportunity availed to the father under the circumstances of the case." 123 Applying these factors, the Kansas Supreme Court concluded that A.A.T.'s biological father was not diligent in taking "affirmative action that manifested a full commitment to parenting responsibilities during the pregnancy and within a short time after." 124

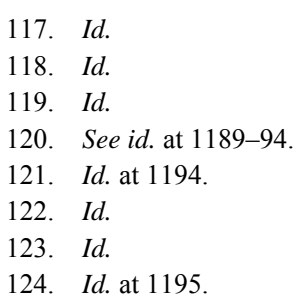


E. Kansas House Bill No. 2482

After the Kansas Supreme Court decided Baby Girl P. in October 2010, the Kansas Legislature introduced Kansas House Bill 2482 by the Committee on Judiciary on January 19, 2012. ${ }^{125}$ The bill was drafted in response to the outcome of Baby Girl P. and a subsequent decision by the Kansas Court of Appeals, Baby Girl B. ${ }^{126}$ which implemented the new standards the Kansas Supreme Court applied in Baby Girl P. ${ }^{127}$ Although the bill died in committee, it proposed some essential amendments to KARA, including provisions clarifying the standards for parental termination in section 59-2136. ${ }^{128}$ These amendments added language requiring the court to consider the "totality of circumstances" when determining whether parental rights should be terminated. ${ }^{129}$ Another provision clarified what constitutes "support" for purposes of section 59-2136(h)(1). ${ }^{130}$ Also worth noting was the addition of the phrase "possible pregnancy" within the statute, which would require the father to provide support for the mother six months prior to the child's birth upon having knowledge of a pregnancy or "possible pregnancy."131

The bill was tabled until May 1, 2012 during a February 16, 2012 meeting of the House Judiciary Committee, ${ }^{132}$ and it was never addressed again. While the bill garnered some support during the committee meeting, some outspoken critics of the bill-described as a "bad bill done with the best intentions"- displayed concern with the "totality of circumstances" addition, fearing it could overrule the "prime directive" in Kansas that biological parents raise their children. ${ }^{133}$ The concern over the addition of the "totality of circumstances" analysis likely caused the bill to die in committee, illustrated by one committee member's comment that "[w]e should leave the decision with the judges who know the facts and issues of the case."134

\footnotetext{
125. H.B. 2482, 84th Leg., Reg. Sess. (Kan. 2012).

126. 261 P.3d 558 (Kan. Ct. App. 2011).

127. See Letter from Austin K. Vincent et al. to Kansas House Judiciary Committee (January 31, 2012), available at http://www.kslegislature.org/li_2012/b2011_12/committees/misc/ctte_h_jud_1_ 20120131_03_other.pdf (expressing support for HB 2482 and listing how the amendments address issues raised in recent case law).

128. See H.B. 2482.

129. Id.

130. See id.

131. See id.

132. Kan. H.R Judiciary Comm., Minutes of the House Judiciary Committee, Feb. 16, 2012, 84th Leg., Reg. Sess., at 11 (2012).

133. Id. at $9-10$.

134. Id. at 10 .
} 


\section{F. The Constitutional Rights of Children and Putative Fathers}

It has long been recognized that children have protected rights under the United States Constitution. ${ }^{135}$ Although there was a time when the law treated children's best interests as synonymous with their parents', children's rights have slowly begun to earn recognition as independent of their parents. ${ }^{136}$ A shift in the way the law regards children has allowed more focus on the independent rights of children who are "the subject of state intervention, both against their parents and against the state when it assumes the parenting responsibility." ${ }^{\prime 37}$ Because children are considered independent individuals under the Constitution, when the state "threatens to take away their liberties or otherwise affect their interests adversely, they are entitled to the protective procedures of the Bill of Rights." 138

The Supreme Court has found that the Due Process Clause requires that a school give a student notice of the charges against her and a chance to respond to them; ${ }^{139}$ that it mandates a juvenile delinquent have notice, counsel, and the right to confront witnesses against her, ${ }^{140}$ and that juvenile delinquency proceedings require proof of guilt beyond a reasonable doubt. ${ }^{141}$ The Supreme Court has also found that children have individual constitutional rights concerning procreation decisions ${ }^{142}$ and First Amendment speech rights. ${ }^{143}$ It is only appropriate based on the variety of other rights granted to children under the Constitution, that before a child is removed from the custody of the only parent she has

135. See Planned Parenthood of Cent. Mo. v. Danforth, 428 U.S. 52, 74 (1976) (“Constitutional rights do not mature and come into being magically only when one attains the state-defined age of majority.").

136. See Hillary Rodham, Children Under the Law, in THE RIGHTS OF CHILDREN 1, 3-4 (Harvard Educ. Review 1974) (describing the change in attitudes towards children's rights from the eighteenth century to the mid-twentieth century).

137. Id. at 5.

138. Id. at 23 (quoting Justice Black, "Undoubtedly this (entitlement to Constitutional guarantees) would be true of an adult defendant, and it would be a plain denial of equal protection of the law - an invidious discrimination - to hold that others subject to heavier punishments could, because they are children, be denied these same constitutional safeguards.").

139. See Goss v. Lopez, 419 U.S. 565, 579 (1975) ("[S]tudents facing suspension and the consequent interference with a protected property interest must be given some kind of notice and afforded some kind of hearing.").

140. See In re Gault, 387 U.S. 1, 41, 56 (1967).

141. See In re Winship, 397 U.S. 358, 368 (1970).

142. See Carey v. Population Servs. Int'1, 431 U.S. 678, 693 (1977); Planned Parenthood of Cent. Mo. v. Danforth, 428 U.S. 52, 74 (1976).

143. See Tinker v. Des Moines Indep. Cmty. Sch. Dist., 393 U.S. 503, 511 (1969) (“[S]tudents are entitled to freedom of expression of their views."). 
ever known, whether it is her biological or adoptive parent, she should also be entitled to the protections of the Due Process Clause.

While biological parents have a fundamental liberty interest in raising their children, "the mere existence of a biological link" does not automatically require protection of these rights. ${ }^{144}$ In Lehr v. Robertson, the United States Supreme Court put limits on the extent of a biological father's fundamental rights when it held that when a putative father participates in the rearing of his child, his interest acquires protection under the Due Process Clause, but "the mere existence of a biological link does not merit equivalent constitutional protection." 145 Further, the Court noted that while the importance of the family does originate with the blood relationship, it also "stems from the emotional attachments that derive from the intimacy of daily association, and from the role it plays in "promot[ing] a way of life." 146 Notably, the Court recognized that the Constitution does not automatically protect that right if a biological father fails to take responsibility for that child, although it is significant that the father's biological connection affords him a unique opportunity to bond with his child. ${ }^{147}$

Courts and legislatures must consider these constitutional rights and interests when determining legal standards for adoption, particularly in the context of terminating parental rights.

\section{ANALYSIS}

In re Baby Girl P. and ambiguity in section 59-2136 have created uncertainty in Kansas adoption law. The Kansas Supreme Court's reversal of the Kansas Court of Appeals decision in Baby Girl P. creates confusion going forward, specifically regarding what minimum level of support a biological father must show to retain parental rights. Baby Girl $P$. also adds an additional level of uncertainty regarding how courts should apply the parental preference doctrine. Kansas precedent determined that the parental preference doctrine was incorporated in section 59-2136, but also interpreted section 59-2136 to require the biological father demonstrate minimum levels of support to avoid termination. ${ }^{148}$ However, the traditional use of the doctrine, independent

\footnotetext{
144. Lehr v. Robertson, 463 U.S. 248, 261 (1983).

145. See id.

146. Id. (alteration in original) (quoting Smith v. Org. of Foster Families for Equal. \& Reform, 431 U.S. 816, 844 (1977)).

147. Id. at 262 .

148. See supra Part II.B.2.
} 
of section 59-2136, was resurrected in Baby Girl P., when the court ruled that biological parent rights must be preserved absent a showing of unfitness, ${ }^{149}$ a decision that contradicted years of Kansas case law.

Where counsel for biological fathers and prospective adoptive parents once had a more definite understanding of what was required of biological fathers to retain their parental rights, the recent decisions have caused confusion about the Kansas appellate courts' stance now and in the future. The Kansas Legislature must amend KARA to clarify this ambiguity and eliminate future unpredictability. The statute should clearly specify the requirements biological fathers must meet to preserve their parental rights, particularly in regards to what is meant by the word "support" in sections 59-2136(h)(1)(C) and (D). While it is imperative that courts protect the biological parents' fundamental rights in raising their children, they should also recognize that children have constitutional due process rights and an interest in quick resolution of their custodial status. ${ }^{150}$ Extended periods of time without custody resolution can be detrimental in a young child's development. ${ }^{151}$ Therefore, while balancing the due process rights of both the parent and child, the Kansas Legislature must also implement new procedures to expedite parental termination proceedings.

\section{A. Effect of the Kansas Supreme Court's Decision in In re Baby Girl P.}

\section{Reversal of Prior Case Law}

The facts surrounding Baby Girl P. were analogous to those in M.D.K., M.R.C., Baby W., and A.A.T.; however, the outcomes in those cases were far different. First, the courts in M.D.K., M.R.C., Baby W., and A.A.T. all found "general" offers of support to be insufficient and instead required the father to take affirmative action to retain parental rights. $^{152}$ Although the father in Baby $W$. challenged the pending adoption and informed the district court he was "ready and willing" and wanted custody of the child as soon as possible, ${ }^{153}$ the Court of Appeals found his "legal efforts [could not] make up for the evidence that he made no reasonable effort to actually support or communicate with the

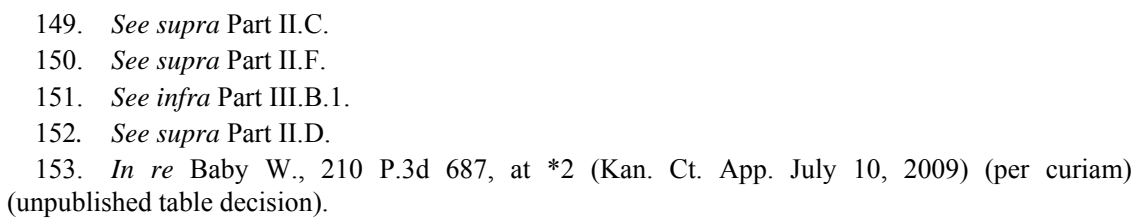


child after learning of [the child's] birth." "154 The Kansas Supreme Court found that although the biological father in A.A.T. asserted that the biological mother knew he would have done anything she requested to support her during her pregnancy, "standing ready and being willing to provide support is insufficient," and "affirmative action must be taken." 155 The biological father in Baby Girl P. did not take affirmative action but rather provided a "general offer of support" when he wrote to the adoptive parents merely stating, "If ever, at any given point and time, if you need something, anything at all I am here for her. So just let me know, [it's] not a problem whatsoever. [It's] my responsibility \& duty and I am ready for that," without actually providing any support for the child. ${ }^{156}$ The Supreme Court, however, found this offer of support to be evidence of the father asserting his desire to care for and communicate with the child. ${ }^{157}$

Additionally, the Kansas Supreme Court altered its interpretation of "incidental visitations, contacts, communications, or contributions" from section 59-2136(h)(2)(B) in Baby Girl P. In M.D.K., the court found blankets and a picture frame that were delivered to the child along with the paternal grandparents' purchase of the birth mother's car for fair market value did not rise to the level of statutory support. ${ }^{158}$ In Baby Girl P., the Kansas Court of Appeals upheld the district court's decision to terminate Baby Girl P.'s father's rights, finding the quilt, clothing, and baby bibs he provided her to be inconsequential or incidental. ${ }^{159}$ In contrast, the Kansas Supreme Court found Baby Girl P.'s father's gifts to be "actions of a father who is attempting to maintain a relationship with his child, not the actions of a father who is neglecting his child," ${ }^{160}$ and determined that although "the statute allows courts to disregard 'incidental' parental activities, [the birth father's] efforts were clearly more than incidental."161 The court found that his conduct went beyond

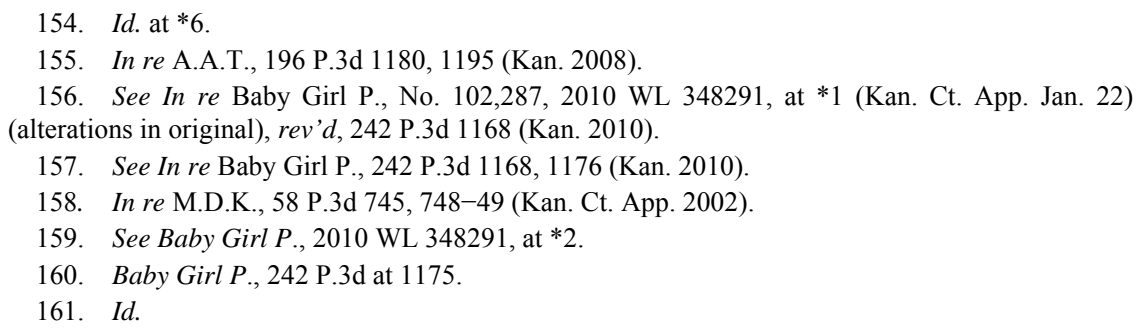


the definition of incidental ${ }^{162}$ and was more than "scarcely casual or insignificant." 163

Evidence in Baby Girl P. that the father "retained counsel, . . f filed court actions to obtain visitation, ... gave gifts, and ... offered to give anything that was needed for his daughter's support," demonstrated to the court a "commitment to assuming the role of a father." 164 However, the support displayed by the father in Baby Girl P. is less than or at most equivalent to that which the birth fathers displayed in M.D.K., M.R.C., Baby W., and A.A.T. The evidence of support the court found when deciding to maintain the father's rights in Baby Girl P. was insufficient for the biological fathers in prior cases. For example, upon notification of his paternity, Baby W.'s father asserted his rights and challenged the adoption. ${ }^{165} \mathrm{He}$ informed the court he was "ready and willing" to take custody of the child and went so far as filing an acknowledgement of paternity, ${ }^{166}$ an action Baby Girl P.'s father did not pursue. The court terminated Baby W's father's rights because he did not voluntarily offer any support despite testifying he would reimburse the adoptive parents at a later date. ${ }^{167}$ The father in M.D.K. asked his parents for help supporting M.D.K.'s mother and they in return bought M.D.K.'s mother's car from her "in hopes of alleviating her financial difficulties."168 The father also delivered a quilt and some baby clothes to the birth mother and sent at least two payments to her after the birth of the child. ${ }^{169}$ The record from A.A.T. revealed that the biological father provided " $\$ 200$ for airfare and '\$20 here, $\$ 20$ there;", however, the court found this to be "insignificant."170 The father in Baby Girl P. provided no financial support to his child or the adoptive parents beyond the delivery of a few small Christmas gifts. ${ }^{171}$

The cases also differ in how the courts handled the birth mother's deception of the father during the pregnancy or her refusal to contact the father before or after birth. In A.A.T., the biological mother lied to the

\footnotetext{
162. The court defined "incidental" as "casual, of minor importance, insignificant, and of little consequence.” Id. (quoting In re McMullen, 691 P.2d 17, 18 (Kan. 1984)).

163. Id.

164. Id.

165. See In re Baby W., 210 P.3d 687, at *1-2 (Kan. Ct. App. July 10, 2009) (per curiam) (unpublished table decision).

166. Id. at *2 (internal quotation marks omitted).

167. See id. at $* 4$.

168. See In re M.D.K., 58 P.3d 745, 747-48 (Kan. Ct. App. 2002).

169. Id. at 748 .

170. In re A.A.T., 196 P.3d 1180, 1195 (Kan. 2008).

171. See In re Baby Girl P., 242 P.3d 1168, 1175 (Kan. 2010).
} 
biological father when she told him she had an abortion. ${ }^{172}$ She further misled a guardian ad litem involved with the case when she provided an incorrect surname for the biological father and asserted she had not had contact with him since the second month of her pregnancy. ${ }^{173}$ This deception caused the court to terminate the father's rights even though he was unaware of the proceeding. ${ }^{174}$ In M.R.C., the mother led the biological father to believe she had miscarried, and the father was also burdened with a protection from abuse order that prevented him from seeing the mother. ${ }^{175}$ The mother in Baby W. actually believed she had miscarried and did not notify the biological father when she eventually gave birth. ${ }^{176}$ Finally, in M.D.K., the father claimed he attempted to contact the mother to ask if she needed support, but she continued to decline and her mother threatened a restraining order against him. ${ }^{177}$ In the court's decision, Judge Beier wrote separately to suggest that even if a mother wants to distance herself from the father, the father must still creatively continue to provide support for the child. ${ }^{178}$

Although the Court of Appeals in Baby Girl P. found that the biological father did not use all available means to investigate the mother's claim of miscarriage as required by prior court decisions, ${ }^{179}$ the Kansas Supreme Court determined that the statute does not require the father to "invade a mother's privacy to determine whether she is pregnant when [he] has sound reasons to believe that she is not." "180

Baby Girl P. overrules more than ten years of Kansas appellate decisions regarding termination of rights for adoption purposes. The evidence of paternal support in Baby Girl P. was less than or at most equal to the support other fathers had shown in at least four prior cases where parental rights were terminated. And while the lengthy analysis of parental rights in the Kansas Supreme Court's decision in A.A.T. seemed to require the termination of Baby Girl P.'s father's rights, the court distinguished the two cases based on the fact that A.A.T.'s father appeared six months after the adoption was finalized, and Baby Girl P.'s

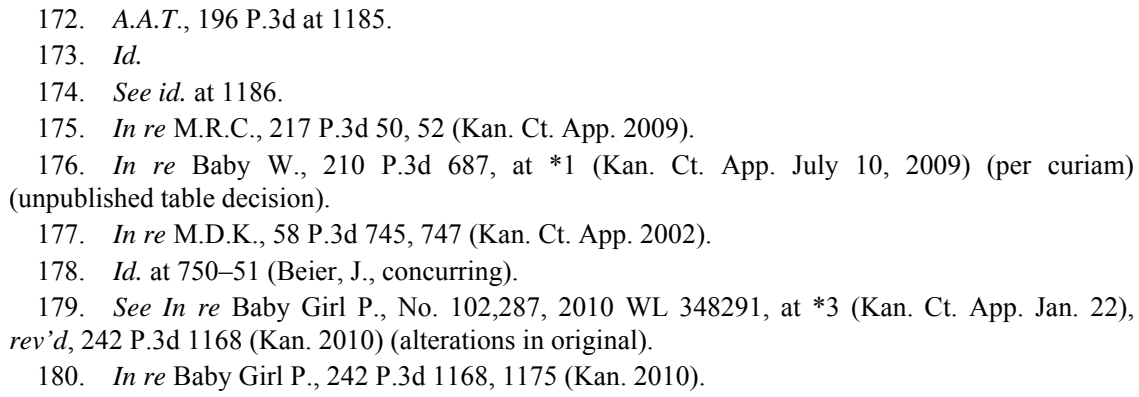


father asserted his rights during the adoption proceeding. ${ }^{181}$ This is an unfair distinction because the court failed to consider that A.A.T.'s father was deceived by the mother and had no knowledge of the birth or adoption proceeding until the mother eventually told him the truth six months later, after his rights had unknowingly been terminated. Upon learning of his paternity, the biological father made relatively the same efforts as Baby Girl P.’s father to assert his parental rights.

\section{Implementation of the Parental Preference Doctrine in Adoption Cases}

While the Kansas Court of Appeals held nearly twenty years ago that the parental preference doctrine is incorporated in section 59-2136 and therefore does not apply on its own, ${ }^{182}$ the Kansas Supreme Court relied solely on the parental preference doctrine in Baby Girl P., stating,

We do not find in the statutory scheme a legislative call to make the assertion of paternal rights a Herculean task. The preservation of a father's relationship with his child is the starting point of a termination proceeding, not the finish line that a father must labor to reach. The statute requires simply that a father make 'reasonable efforts' to support or communicate with his child. ${ }^{183}$

This appears to create a presumption that rights should remain intact absent compelling evidence of abuse or neglect, while prior case law required "affirmative action to manifest a full commitment to parenting responsibilities." 184 Confusion about the minimum levels of support a biological father must demonstrate causes uncertainty for both the adoptive parents and the biological parent. Courts must decide once and for all how to apply the parental preference doctrine.

\section{B. Preventing Uncertainty in Future Adoption Cases}

1. How Disruptions in Permanency Effect Children

Kansas has an interest in an early determination of the "rights, interests, and obligations of all parties" involved a child's life. ${ }^{185}$ Kansas

\footnotetext{
181. See id. at 1175.

182. See supra Part II.B.2.

183. See Baby Girl P., 242 P.3d at 1174 (citing KAN. StAT. ANN. § 59-2136(h)(1)(C) (Supp.

184. See In re M.R.C., 217 P.3d 50, 56 (Kan. Ct. App. 2009).

185. See In re A.A.T., 196 P.3d 1180, 1195 (Kan. 2008) (citing Lehr v. Robertson, 463 U.S.
} 2012)). 
also has an interest in encouraging adoptions and protecting the adoption process by "eliminating the risk of unnecessary controversy that might impair ... finality." 186 Uncertainty regarding whether biological fathers may contest adoptions could result in "dissuad[ing] prospective adoptive parents from attempting to adopt the children of unwed mothers who ... have chosen for whatever reason not to keep their child and raise it themselves." 187 This would "frustrate [a] state's clear interest in encouraging such adoptions and providing stable homes for children."188

According to The Best Interests of the Child, a book that "ha[s] become the standard for assessing child placement decision-making in this country," 189 children are treated differently than adults under the law because they are "dependent beings who are not fully competent to determine and safeguard their own interests." an interest in assuring each child a "membership" within a family including at least one parent. ${ }^{191}$ Children's mental states differ drastically from adults'. ${ }^{192}$ Their relationships with parental figures are essential to their development. ${ }^{193}$ For example, an infant's attachment to her parents comes from her parents providing the daily "physical care, nourishment, comfort, affection, and stimulation" she needs to thrive. ${ }^{194}$ A parent who satisfies these needs becomes the "psychological parent."195 A child with a psychological parent becomes a "wanted child" who "feels loved, valued, and wanted by that [parent]," and therefore has a higher chance of achievement because she is convinced of her human value. ${ }^{196}$ Adoptive parents who have custody over a child in her early infancy have a greater chance of developing a psychological

\footnotetext{
248, 262-64 n.20 (1983)).

186. See id. (citing Lehr, 463 U.S. at 262-64 n.20).

187. Id. (second alteration in original) (quoting In re Michael H., 898 P.2d 891, 898 (Cal. 1995) (en banc)).

188. Id. (quoting Michael H., 898 P.2d at 898).

189. Barbara F. Nordhaus, Preface to JosePh Goldstein ET. AL., THE Best InTERESTS OF THE CHILD, at xi (1996).

190. GOLDSTEIN ET. AL., supra note 18989, at 5 .

191. Id.

192. See id. at 9 (explaining that children "differ from their elders in their mental nature, their functioning, their understanding of events, and their reactions to them").

193. See id. ("[C]hildren have no psychological conception of blood-tie relationships until quite late in their development.... What matters to them is the pattern of day-to-day interchanges with the adults who take care of them and who, on the strength of such interactions, become the parent figures to whom they are attached.").

194. Id. at 11 .

195. Id. (internal quotation marks omitted).

196. Id. at 13 .
} 
parent-child relationship. ${ }^{197}$ Therefore, a delay in the finalization of an adoption or the placement of the child in a stable home may result in a reduction of critical time to make a child feel "wanted." 198 Further, research shows that infants who lose their attachment to their primary caregiver have less advanced communication skills and their motor and cognitive development suffers. ${ }^{199}$ These infants also can "become very disturbed if they are separated from their primary caregivers," which may cause "conduct disorders and antisocial development."200

\section{Expedited Termination Proceedings}

Because continuity of relationships is essential for children, and disruptions of continuity can result in detriment to healthy development, particularly with very young children, adoption proceedings should be accelerated. ${ }^{201}$ Uncertainty in adoptions can negatively affect the ability to stabilize the new parent-child relationship due to the lingering fears of biological parents revoking consent or coming forward to assert parental rights. $^{202}$ The Kansas Legislature must make it a priority to take necessary action so that termination proceedings are expedited, whether through legislative action or changing the courts' internal procedures.

Children sense time differently than adults, and the passage of time for children is magnified, which aggravates anxiety. ${ }^{203}$ While adults measure the passage of time by the clock or a calendar, children sense time passage based on the "urgency of their instinctual and emotional needs" and are particularly sensitive to periods of long separation. ${ }^{204}$

197. Id

198. See id. (noting that "temporary placements are often associated with deprivation, disruption, or broken attachments.").

199. See Marcus T. Boccaccini \& Eleanor Willemsen, Contested Adoption and the Liberty Interest of the Child, 10 ST. THOMAS L. REV. 211, 218 (1998) (citing ATTACHMENT IN THE PRESCHOOL YEARS 200-01 (Mark T. Greenberg et al. eds., 1990)).

200. Melissa LaBarge, Comment, "C" Is for Constitution: Recognizing the Due Process Rights of Children in Contested Adoptions, 2 U. PA. J. CONST. L. 318, 320 (1999) (quoting Paige Kerchner Kaplan, Comment, Putting the Child First in Custody Battles Between Biological Fathers and Adoptive Parents, 35 SANTA ClARA L. REV. 907, 933, 935 (1995)) (internal quotation marks omitted).

201. See GoldSTEIN ET. AL., supra note 18989, at 22-23 (arguing that the waiting period in adoptions is detrimental and should be eliminated).

202. Id. at 22 .

203. Ctr. on Children \& The Law, Am. Bar Ass'N, A Judge's Guide: Making ChildCEnTERED Decisions In CuSTODY CASES 15 (Diane Boyd Rauber ed., 2001) (quoting NAT'L Council of Juvenile \& Family Court Judges, Resource Guidelines: Improving Court Practice in Child Abuse and Neglect CASES (1995)).

204. See GOLDSTEIN ET. AL., supra note 18989 , at 41-42. 
Courts must recognize the sensitivity of child custody cases, particularly regarding disputed adoptions, and expedite litigation at the appellate level because, "[t]he longer a child remains with the adult who retains custody pending appeal, the less likely... will it be appropriate to change her placement."205

Further, any changes to the timeliness of termination proceedings must be developed considering both the due process rights of the biological parent and the child. Any procedure should allow enough time for the biological parent to assert his rights and demonstrate his desire to parent, while at the same time protecting a child's due process rights and promptly resolving the child's status.

The federal government recognized the need to expedite proceedings involving children when it enacted the Adoption and Safe Families Act of 1997 (ASFA). ${ }^{206}$ The ASFA sought to lessen the amount of time children spend in state custody by shortening "time frames for court hearings and permanent placement." 207

In response to legislation such as this, the Kansas Supreme Court requested a study of the parental termination appeals processes, setting a goal to identify ways to "expedite those appeals while preserving the due process rights of all involved." 208 In 2007, the Judicial Council's Appeals from Termination of Parental Rights Advisory Committee made a variety of recommendations that could be implemented to reduce delays in appellate proceedings. ${ }^{209}$ The committee noted that the National Council of Juvenile and Family Court Judges recommends a period of no longer than 150 days from the issuance of the trial court order for a termination proceeding to be finalized in the appeals process. $^{210}$ Among its recommendations, the committee suggested revisions to the Kansas Supreme Court Rules and changes to appellate procedures including addition of a special provision to the Notice of Appeal that indicates it is a termination proceeding, forming a new

205. Id. at 44 .

206. Pub. L. No. 105-89, 111 Stat. 2115 (codified as amended in scattered sections of 42 U.S.C.).

207. Evelyn Lundberg Stratton, Expediting the Adoption Process at the Appellate Level, 28 CAP. U. L. REV. 121, 122 (1999) (citing 42 U.S.C. § 675(5)(C) (1994 \& Supp. III 1997)).

208. See APPEALS FROM TERMINATION OF PARENTAL RIGHTS ADVISORY

COMM., KAN. Judicial COUNCIL, REPORT OF THE JudiCIAL COUNCIL APPEALS FROM TERMinAtion OF PARENTAL RIGHTS ADVISORY COMMITTEE 1 (2007), http://www.kansasjudicialcouncil.org/ Documents/Studies\%20and\%20Reports/Recent\%20Reports/Rpt_ATPR_FinalReport_Nov2007.pdf.

209. See id. at 5-18 (recommending certain changes to appellate procedure as well as other areas of the court system).

210. Id. at 2 . 
docketing statement unique to termination proceedings, and limiting the briefing period for termination appeals. ${ }^{211}$ More than five years after the committee made its recommendations, none of the proposed Supreme Court rule changes have been implemented in Kansas.

It is time for the Kansas Legislature to recognize the necessity of expediting the appeals process when the termination of parental rights for adoption purposes are at issue, so that the status of children does not remain pending for detrimentally long periods of time. Immediate action must be taken, such as implementing those recommendations from the Kansas Judicial Council or passing legislation mandating expedited procedures in adoption or parental termination appeals, ${ }^{212}$ to lift the veil of uncertainty currently surrounding adoptions in Kansas.

\section{Amendments to Section 59-2136}

Additionally, the Kansas Legislature must amend KARA to clarify the requirements a biological father must meet to maintain his parental rights under section 59-2136. Adding more specific language and detailed definitions of troublesome phrases such as "support" could help courts set a more consistent standard when making difficult termination decisions.

The ambiguity of section 59-2136 has opened the door for Kansas courts to produce inconsistent results when deciding whether to terminate parental rights, which in turn will detrimentally affect the children involved. While section 59-2136(h)(1) provides seven conditions under which a court may terminate parental rights, ${ }^{213}$ there is

\footnotetext{
211. See id. at 5-13.
}

212. Many states have statutory provisions that mandate expedited processes involving adoption and parental termination. See, e.g., ME. Rev. StAT. ANN. tit. 18-A, § 9-309(b) (2012) (providing that "[a]n appeal from any [adoption] order ... must be expedited"); N.Y. DOM. REL. LAW §112a(3) (McKinney 2010) (requiring court administrators at the trial level to establish rules to expedite adoption proceedings); TEX. FAM. CODE ANN. § 109.002(a) (West Supp. 2012) (providing that appeals involving parental termination are to be given preference and accelerated over other civil cases); W. VA. CODE ANN. § 48-22-704(f) (West 2002) (providing that any appeals from adoption orders shall be considered and resolved "as expeditiously as possible").

213. The seven conditions are as follows:

(A) The father abandoned or neglected the child after having knowledge of the child's birth;

(B) the father is unfit as a parent or incapable of giving consent;

(C) the father has made no reasonable efforts to support or communicate with the child after having knowledge of the child's birth;

(D) the father, after having knowledge of the pregnancy, failed without reasonable cause to provide support for the mother during the six months prior to the child's birth;

(E) the father abandoned the mother after having knowledge of the pregnancy; 
little authority to help the court determine what evidence is sufficient for termination. Some Kansas appellate decisions have interpreted the statute to mean that "a father has a duty to take affirmative action to manifest a full commitment to parenting responsibilities and to exercise reasonable diligence to discover whether the mother has lied to him concerning the existence of the child." ${ }^{214}$ However Baby Girl P. suggests a father must make only "reasonable efforts" to maintain his rights. ${ }^{215}$

As evidenced by the discrepancy in decisions by Kansas courts, "support" as it appears in sections 59-2136(h)(1)(C) and (D) is a troublesome word. Whether the term is intended to mean financial or emotional support is unclear, and various cases decided by Kansas courts have produced different results. ${ }^{216}$ Further, the level of support is also undefined. While the statute instructs that courts may disregard "incidental visitations, contacts, communications or contributions," Kansas courts have been inconsistent in interpreting what amount of contact or financial resources qualifies as more than "incidental.,"218

Kansas House Bill No. 2482, considered in 2012, attempted to reconcile this disparity by adding a provision that defined "support." 219 The proposed amendment added section 59-2136(j), which stated, "[f]or the purposes of this section, 'support' means any tender of (1) significant monetary support or (2) significant nonmonetary support." 220 While it remains unknown how the addition of this provision would affect future court decisions, members of the Kansas Legislature at least recognized the need to qualify the meaning of "support." Iowa's termination statute, for example, provides a clearer, more specific outline for resolving these difficult issues. ${ }^{221}$ This statute utilizes an affirmative list of actions a

(F) the birth of the child was the result of rape of the mother; or

(G) the father has failed or refused to assume the duties of a parent for two consecutive years next preceding the filing of the petition.

KAN. StAT. ANN. § 59-2136(h)(1) (Supp. 2012).

214. In re M.R.C., 217 P.3d 50, 56 (Kan. Ct. App. 2009) (citing In re A.A.T., 196 P.3d 1180, 1184 (Kan. 2008)).

215. In re Baby Girl P., 242 P.3d 1168, 1174 (Kan. 2010) (quoting Kan. STAT. ANN. § 59-

2136(h)(1)(C)) (internal quotation marks omitted).

216. See supra Part III.A.1.

217. KAN. STAT. ANN. §59-2136(h)(2)(B).

218. See supra Part III.A.1.

219. See H.B. 2482, 84th Leg., Reg. Sess. (Kan. 2012).

220. Id.

221. See IowA CoDE ANN. § 600A.8 (West Supp. 2013). 
parent must demonstrate to preserve his parental rights ${ }^{222}$ and includes a number of factors, including a few directed specifically at putative fathers, ${ }^{223}$ that a court may consider when determining whether the parent demonstrated the requisite actions to maintain his rights. The statute expands on the definition of support by providing that a parent may pay "a fair and reasonable sum, in accordance with the putative father's means," 224 and also specifies that a father must show "a willingness to assume custody of the child rather than merely objecting to the termination of parental rights." 225 These two provisions alone would provide Kansas courts with additional tools to help harmonize their inconsistent parental termination decisions, particularly in regards to how much financial support is sufficient.

Additionally, the Judicial Council Family Law Advisory Committee issued a report in 2010 regarding Senate Bill 255, which proposed amending the existing law concerning stepparent adoptions. ${ }^{226}$ In this report the committee recommended the legislature consider "amending the statutes in order to provide consistency with regard to the standards used to determine fitness of a parent."227 The committee recommended that the legislature utilize the Revised Kansas Code for Care of Children $(\text { CINC Code })^{228}$ as a basis for the amendments. ${ }^{229}$ The CINC Code, found in section 38-2269 of the Kansas Statutes, suggests a list of factors to consider when making decisions about termination of parental rights. ${ }^{230}$ These CINC Code factors provide some of the specificity that

222. See id. §600A.8(3)(a)(1) ("If the child is less than six months of age when the termination hearing is held, a parent is deemed to have abandoned the child unless the parent does all of the following: (a) Demonstrates a willingness to assume custody of the child rather than merely objecting to the termination of parental rights. (b) Takes prompt action to establish a parental relationship with the child. (c) Demonstrates, through actions, a commitment to the child.").

223. See id. $\$ \S 600 \mathrm{~A} .8(3)(\mathrm{a})(2)(\mathrm{c})-(\mathrm{d}), 600 \mathrm{~A} .8(3)(\mathrm{c})$.

224. Id. $\S 600 \mathrm{~A} .8(3)(\mathrm{a})(2)(\mathrm{d})$.

225. Id. $\S 600 \mathrm{~A} .8(3)(\mathrm{a})(1)(\mathrm{a})$.

226. See FAMily LAW AdVisory COMM., Kan. Judicial COUNCIL, REPORT OF THE JUdiCIAL COUNCIL FAMILY LAW ADVISORY COMMITTEE ON 2010 SB 522, at 6 (2010), http://www.kansas judicialcouncil.org/Documents/Studies\%20and\%20Reports/2011\%20Reports/Family\%20law\%20SB 522.pdf.

227. Id

228. Kan. STAT. ANN. § 38-2269 (Supp. 2012).

229. FAMILY LAW ADVISORY COMM., supra note 226, at 6-7.

230. See KAn. Stat. AnN. § 38-2269(b). These factors include:

(1) Emotional illness, mental illness, mental deficiency or physical disability of the parent, of such duration or nature as to render the parent unable to care for the ongoing physical, mental and emotional needs of the child;

(2) conduct toward a child of a physically, emotionally or sexually cruel or abusive nature;

(3) the use of intoxicating liquors or narcotic or dangerous drugs of such duration or 
is lacking in the current adoption statute. Drawing from the proposals in House Bill No. 2482, examples from other state statutes, and the CINC Code, the Kansas Legislature should have the necessary tools to draft amendments to help clarify the ambiguity in the current statute.

Clarifying and adding specific requirements a biological father must meet to maintain his parental rights is essential to prevent future uncertainty for adoptive parents. It is particularly important to clarify the meaning of "support" found in section 59-2136(h)(1)(C) and (D). Additionally, courts should consider the children's due process rights and make custody related cases, especially those on appeal, a high priority and expedite these decisions to make a final determination of a child's status. Expedited procedures will help reach finality for all parties so that cases, such as the two-and-a-half year litigation in Baby Girl P., do not remain unresolved for extended periods of time.

\section{CONCLUSION}

Adoption plays a positive role in society, allowing biological parents to relinquish their rights to allow a child to be raised in home with parents who can better provide them with a stable, loving life. While KARA implemented processes to make the adoption process fair and

nature as to render the parent unable to care for the ongoing physical, mental or emotional needs of the child;

(4) physical, mental or emotional abuse or neglect or sexual abuse of a child;

(5) conviction of a felony and imprisonment;

(6) unexplained injury or death of another child or stepchild of the parent or any child in the care of the parent at the time of injury or death;

(7) failure of reasonable efforts made by appropriate public or private agencies to rehabilitate the family;

(8) lack of effort on the part of the parent to adjust the parent's circumstances, conduct or conditions to meet the needs of the child; and

(9) whether the child has been in extended out of home placement as a result of actions or inactions attributable to the parent and one or more of the factors listed in subsection (c) apply.

Id. Section 38-2269(c) states:

In addition to the [factors in section 38-2269(b)], when a child is not in the physical custody of a parent, the court, shall consider, but is not limited to, the following:

(1) Failure to assure care of the child in the parental home when able to do so;

(2) failure to maintain regular visitation, contact or communication with the child or with the custodian of the child;

(3) failure to carry out a reasonable plan approved by the court directed toward the integration of the child into a parental home; and

(4) failure to pay a reasonable portion of the cost of substitute physical care and maintenance based on ability to pay. 
efficient, unfortunately there are situations in which courts must make difficult decisions about who should raise the child. A biological parent has a constitutionally protected right to raise his child. However, in certain messy situations, a biological father, who may know very little about the pregnancy and birth of his child, faces termination of his parental rights for an adoption proceeding to be finalized. While Kansas courts have required the biological father to show sufficient support for the child to retain his rights, a recent Kansas Supreme Court decision seemed to reverse all prior case law, leaving ambiguity and uncertainty in future adoption proceedings. Kansas courts and the Kansas Legislature must act to reconcile these discrepancies in favor of a law that has better defined standards for what a biological father must do to retain his parental rights, and expedites appellate procedures considering the child and biological parent's rights so that all parties can reach a quick and final determination of custody. 